\title{
ВИВЧЕННЯ КЛАСИФІКАЦІЇ ІММУНОСЕНСОРІВ З ПОГЛЯДУ НА МЕДИЧНІ ЗАВДАННЯ
}

\author{
В. П. Марценюк, А. Клос-Вітковська, А. С. Сверстюк ${ }^{1}$ \\ Університет Бєльсько-Бяли, Республіка Польща \\ ${ }^{1}$ ДВНЗ «Тернопільський державний медичний університет \\ імені І. Я. Горбачевського МОЗ України»
}

\begin{abstract}
Імуносенсори та іммунотести широко використовують в медицині, де зразки крові, сечі або слини дозволяють визначати концентрації морфіну, прогестерону, естрадіолу, дофаміну, інсуліну.

В роботі розглядається використання імуносенсорів для таких медичних проблем, як кількісне визначення альфра-сретопротеїну, визначення білка р53 в сечі з метою діагностики раку сечового міхура, амперометричне визначення карциноембріонального антигену, визначення галектину-3 як біомаркера серцевої недостатності, виявлення поверхневого антигену гепатиту $\mathrm{B}$, чутливе детектування маркера пухлини при визначенні рівня у сироватці крові пацієнтів з раком молочної залози.
\end{abstract}

Ключові слова: біосенсор, імуносенсор, антитіла, антиген.

\section{STUDY OF CLASSIFICATION OF IMMUNOSENSORS FROM VIEWPOINT OF MEDICAL TASKS}

\author{
V. P. Martsenyuk, A. Klos-Witkowska, A. S. Sverstyuk ${ }^{1}$ \\ University of Bielsko-Biala, the Republic of Poland \\ ${ }^{1}$ SHEE «l. Horbachevsky Ternopil State Medical University \\ of the Ministry of Health of Ukraine»
}

\begin{abstract}
Immunosensors and immunotests are commonly used in medicine, where blood, urine or saliva samples enable concentrations of morphine, progesterone, estradiol, dopamine, insulin to be determined.

In this work, the use of immunosensors for the following medical problems is considered: for the quantitative detection of alpha-fetoprotein, for determination of p53 protein in urine for diagnostics bladder cancer, for amperometric determination of carcinoembryonic antigen, for the determination of galectin-3, as biomarker of heart failure, for detecting hepatitis B surface antigen, for sensitive detection of tumor marker for determination of serum level in breast cancer patients.
\end{abstract}

Key words: biosensor, immunosensor, antibody, antigen.

\section{ИЗУЧЕНИЕ КЛАССИФИКАЦИИ ИММУНОСЕНСОРОВ С ТОЧКИ ЗРЕНИЯ МЕДИЦИНСКИХ ЗАДАЧ}

\author{
В. П. Марценюк, А. Клос-Витковска, А. С. Сверстюк ${ }^{1}$ \\ Университет Бельско-Бялы, Республика Польша

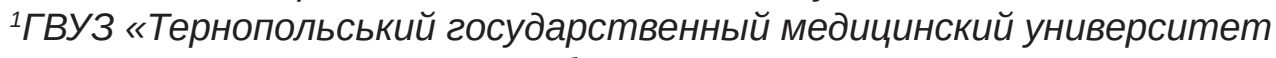 \\ имени И. Я. Горбачевского МЗ Украины»
}

\begin{abstract}
Иммуносенсоры и иммунотесты широко используются в медицине, где образцы крови, мочи или слюны позволяют определять концентрации морфина, прогестерона, эстрадиола, дофамина, инсулина.

В данной работе рассматривается использование иммуносенсоров для следующих медицинских проблем: количественного определения альфа-фретопротеина, определения белка р53 в моче с целью диагностики рака мочевого пузыря, амперометрического определения карциноэмбрионального антигена, определения галектина-3 как биомаркера сердечной недостаточности, выявления поверхностного антигена гепатита В, чувствительного детектирования маркера опухоли при определении уровня в сыворотке крови пациентов с раком молочной железы.
\end{abstract}

Ключевые слова: биосенсор, иммуносенсор, антитела, антиген.

() В. П. Марценюк, А. Клос-Вітковська, А. С. Сверстюк 
Introduction. Immunosensors are affinity ligandbased biosensor solid-state devices in which the immunochemical reaction is coupled to a transducer. The fundamental basis of all immunosensors is the specificity of the molecular recognition of antigens by antibodies to form a stable complex. This is similar to the immunoassay methodology. Immunosensors can be categorized based on the detection principle applied. The main developments are electrochemical, optical, and microgravimetric immunosensors. In contrast to immunoassay, modern transducer technology enables the label-free detection and quantification of the immune complex [1]. The analysis of trace substances in environmental science, pharmaceutical and food industries is a challenge since many of these applications demand a continuous monitoring mode. The use of immunosensors in these applications is most appropriate.

When reviewing scientific reports on applications of immunosensors, the following two terms are most frequently used, namely: immunoassay (immunotests) and immunosensor. However, there is a difference between them. In biosensors the receptor layer can be used many times for detection purposes, thus enabling continuous monitoring. For immunoassay, after an immunological reaction is completed, and before the next measurement is made, the receptor layer should be regenerated [6].

Immunosensors and immunotests are commonly used in environmental protection where there is a need of monitoring of water quality [10], toxic chemicals, pesticides, chemical weapons [18], and in food analysis [19], but they are most often used in medicine [17], where blood, urine or saliva samples enable concentrations of morphine, progesterone, estradiol, dopamine, insulin to be determined [18].

ELISA (Enzyme Linked Immune Sorbent Assay) is the oldest and also the most frequently used immunological test due its low cost and high repeatability. This test was used, among others, to detect malaria [7], HIV diagnosis [13], or toxoplasmosis [15].

Among a large family of biosensors there are immunosensors that in a sensitive selective receptor layer contain an immobilized biological component (antibody, antigen, hapten) being an immunological receptor for recognition of measurable analyte molecules.

The receptor layer directly contacts the transducer layer where the biological interaction is transformed into a measurable signal [6, 9].
Immunosensors are those biosensors that use a specific reaction between an antibody and an antigen or small molecules called haptens.

Haptens elicit the production of antibodies only when attached to larger molecules such as proteins.

Antibodies as immune-related proteins are very often referred to as immunoglobulins.

They consist of four polypeptide chains: two heavy and two light chains. They form Y-shaped molecules of molecular weight greater than $1.5 \mathrm{kDa}$. There are two types of light chains: $\kappa$ and $\lambda$ types and five types of heavy chains: $\alpha, \delta, \varepsilon, \gamma, \mu$ types.

Depending on the type of heavy chain present in an antibody, immunoglobulins are divided into five classes of different structure and immunological functions.

Immunoglobulins are used by the immune system to identify and neutralize foreign bodies, and show also binding properties to an antigen.

The types of antibodies and its function as well as references to its comprehensive description are listed in the book [16].

Further we present the most widely used immunosensors together with their characteristics.

\section{Electrochemical immunosensors for the quantitative detection of alpha-fetoprotein (AFP).}

A novel and ultrasensitive sandwich-type electrochemical immunosensor was designed for the quantitative detection of AFP using multifunctional mesoporous silica (MCM-41) as platform and label for signal amplification. MCM-41 has high specific surface area, high pore volume, large density of surface silanol groups ( $\mathrm{Si}-\mathrm{OH}$ ) and good biocompatibility. MCM-41 functionalized with 3-aminopropyltriethoxysilane, gold nanoparticles (Au NPs) and toluidine blue could enhance electrochemical signals [14]. Moreover, primary antibodies (Ab1) and secondary antibodies (Ab2) could be effectively immobilized onto the multifunctional MCM-41 by the interaction between $\mathrm{Au}$ NPs and amino groups $(-\mathrm{NH} 2)$ on antibodies. Using multifunctional MCM-41 as a platform and label could greatly simplify the fabrication process and result in a high sensitivity of the designed immunosensor. Under optimal conditions, the designed immunosensor exhibited a wide liner range from $104 \mathrm{ng} / \mathrm{mL}$ to $103 \mathrm{ng} / \mathrm{mL}$ with a low detection limit of $0.05 \mathrm{pg} / \mathrm{mL}$ for AFP. The designed immunosensor showed acceptable selectivity, reproducibility and stability, which 
could provide potential applications in clinical monitoring of AFP.

\section{Amperometric immunosensors.}

2.1. Amperometric immunosensor for determination of $p 53$ protein in urine with carbon nanotubes / Au NPs. Since p53 protein has become recognized biomarker for both diagnostic and therapeutic purposes in oncological diseases with particular relevance for bladder cancer, it is highly desirable to search for a novel sensing tool for detecting the patient's p53 level at the early stage. In [8] there is reported the first study on the development and validation of a novel disposable competitive amperometric immunosensor for determination of p53 protein at subnanomolar levels, based on p53 immobilization on Au NPs / carbon nanotubes modified screen-printed carbon electrodes. The assay protocol requires the use of single anti-p53 mouse monoclonal antibody (DO-7 clone), able to recognize both wild-type and mutant p53. The developed immunosensor as well as the protocol of the electrochemical immunoassay were optimized by means of an experimental design procedure to assess the suitability of the device to be validated and applied for the determination of p53 in untreated and undiluted urine samples. It was found that the developed competitive immunodevice was able to achieve wide linear range detection of wild-type p53 from 20 pM to $10 \mathrm{nM}$ with a low detection limit of $14 \mathrm{pM}$ in synthetic urine samples, suggesting the sensor's capability of working in a complex sample matrix. The excellent performance results also in terms of selectivity, trueness and precision, coupled with the advantages of an easy preparation and low-cost assay in contrast to other methods which require very complex, time-consuming and costly nanostructured architectures, makes the developed competitive immunosensor an analytically robust diagnostic tool, valuable for implementation of screening and follow-up programs in patients with urologic malignancies.

2.2. Immunosensor for amperometric determination of carcinoembryonic antigen (CEA).

2.2.1. Immunosensor for amperometric determination of CEA using Au NP $\mathbf{N P}_{\mathrm{s}}$-titanium dioxide-graphene (AuNP $-\mathrm{TiO}_{2}$-graphene) nanocomposites. A novel and sensitive sandwich immunosensor for amperometric determination of CEA was designed using $\mathrm{AuNP}_{5}-\mathrm{TiO}_{2}$-graphene nanocomposites. Dopamine-functionalized graphene was firstly prepared by $\pi$-stacking interaction, and $\mathrm{TiO}_{2}$ was then attached to the surface of dopamine-graphene by the specificity and high affinity of enediol ligands to Ti (IV). Afterwards, $\mathrm{AuNP}_{\mathrm{s}}$ - $\mathrm{TiO}_{2}$-graphene nanocomposites were synthesized with photoreduction approach under ultraviolet irradiation. The morphology and conductivity of the as-prepared nanocomposites were characterized by transmission electron microscopy, Fourier transform infrared spectra, $\mathrm{X}$-ray powder difraction, cyclic voltammetry and electrochemical impedance spectroscopy. Taking the advantage of large specific surface area and excellent biocompatibility, AuNP s could covalently link horseradish peroxidase labeled secondary antibody (HRP-Ab ${ }_{2}$ ) through the interaction between $\mathrm{AuNP}_{\mathrm{s}}$ and mercapto or primary amine groups of HRP-A $b_{2}$ for sandwichtype immunosensor construction. Under optimum conditions, the modified electrode exhibited a linear current response to CEA concentration in a wide range of $0.005-200 \mathrm{ng} / \mathrm{mL}(\mathrm{R}=0.994)$ with low detection limit of $3.33 \mathrm{pg} / \mathrm{mL}(\mathrm{S} / \mathrm{N}=3)$ [12].

\subsubsection{Ectrochemical immunosensor was} developed fordetecting CEA based on Ag/ $\mathrm{MoS}_{2} @ \mathrm{Fe}_{3} \mathrm{O}_{4}$ and an analogous 2 enzyme linked immunosorbent assay (ELISA) method. In this work, an ultrasensitive electrochemical immunosensor was developed for detecting CEA based on Ag/ $\mathrm{MoS}_{2} @ \mathrm{Fe}_{3} \mathrm{O}_{4}$ and an analogous 2 enzyme linked ELISA method. The fabrication process was conducted by using 96-well microplate and the detection process was executed on magnetic glassy carbon electrode (MGCE), which was named analogous ELISA method. The technique of total internal reflection fluorescence was firstly employed to verify the feasibility of the proposed method MANUSCRIPT sandwich-type strategy was applied for the fabrication of the immunosensor and $\mathrm{Ag}$ / $\mathrm{MoS}_{2} @ \mathrm{Fe}_{3} \mathrm{O}_{4}$ was used as label [3].

Simultaneously, Ag nanoparticles (Ag $\mathrm{NP}_{s}$ ) were applied for modifying the MGCE as sensing platform due to its excellent electroconductivity. Ag/ $\mathrm{MoS}_{2} @$ $\mathrm{Fe}_{3} \mathrm{O}_{4}$ could firmly attached on the surface of MGCE thanks to the magnetic property of $\mathrm{Fe}_{3} \mathrm{O}_{4}$. Differential pulse voltammetry was applied for the detection of CEA and electrochemical impedance spectroscopy confirmed the successful fabrication of the immunosensor. Under optimal experimental conditions, a linear response was achieved in the range of $0.0001-20 \mathrm{ng} / \mathrm{mL}$ with a low. 


\section{Electrochemical immunosensor for the determination of galectin-3, a biomarker of heart failure.}

In the work [5] there is presented an electrochemical immunosensor for the determination of galectin-3 (Gal-3), a biomarker of heart failure. A glassy carbon electrode (GCE) was modified with a film of a composite made from the $\mathrm{N}$-doped graphene nanoribbons immobilized Fe-based-metal-organic frameworks deposited with Au NPs (N-GNRs-FeMOFs@AuNP). Ab1 against Gal-3 (Gal-3-Ab1) was immobilized on the Au NPs on the surface of the modified GCE which then was blocked with bovine serum albumin. Signal amplification is crucial for obtaining low detection limits in biosensors. Here, a relatively simple and ultrasensitive sandwichtype electrochemical immunosensor based on novel signal generation and amplification was developed for the determination of Gal-3. A kind of novel redox-active species, AuPt-methylene blue (AuPtMB) nanocomposites, was synthesized by a one-pot method for the first time. Wherein, methylene blue as a kind of the electron transfer mediators in an amperometric biosensor is responsible for electron production and signal amplification [5]. The rod-like AuPt-MB nanohybrids displayed uniform morphology and good electrochemical activity and can combine with the second antibodies against Gal-3 (Gal-3- $\left.\mathrm{Ab}_{2}\right)$. And the AuPt-MB-Ab ${ }_{2}$ coupled with the N-GNRs-Fe$\mathrm{MOF}_{s} @ \mathrm{AuNP}_{\mathrm{s}}-\mathrm{Ab} 1$ to form the sandwich type format that can greatly enhance the biosensor's sensitivity. Under optimal conditions, the designed immunosensor exhibited a linear concentration range from $100 \mathrm{fg} / \mathrm{mL}$ to $50 \mathrm{ng} / \mathrm{mL}$, with a low detection limit of $33.33 \mathrm{fg} / \mathrm{mL}$ $(\mathrm{S} / \mathrm{N}=3)$ for Gal-3 in spiked serum. Additionally, the designed immunosensor showed acceptable selectivity, reproducibility and stability. The satisfactory results in analyzing human serum samples indicated potential application promising in monitoring biomarkers.

\section{Sandwich-type immunosensor for detecting hepatitis B surface antigen.}

A novel thionine unites with platinum nanowire in laid globular SBA-15 (Pt NWs@g-SBA-15/Thi) not only utilizes as an efficient electrical signal probe but also constitutes an amplifying system with doubledeck gold film (D-Au film) have been applied to the fabrication of sandwich-type immunosensor for detecting hepatitis B surface antigen $\left(\mathrm{HB}_{\mathrm{s}} \mathrm{Ag}\right)$. The $\mathrm{D}$-Au film can accelerate the electron transfer on the electrode interface due to the tunneling effect between the two Au films and can improve the load capacity of Ab1 because of the good biocompatibility. The Pt NWs@g-SBA-15/Thi with uniform globular morphology not only can effectively reduce the spatial limitation for loading the Ab2 but also can provide outstanding pore accessibility of guest species from outside and offer catalytically active sites in a large scale. Besides, the presence of Thi can well enhance the electrical conductivity of $\mathrm{Pt}$ NWs@g-SBA-15/Thi. With the good cooperation between D-Au film and Pt NWs@g-SBA-15/Thi, a linear relationship between current signals and the concentrations of HBs Ag was obtained in the wide range from $10 \mathrm{fg} / \mathrm{mL}$ to $100 \mathrm{ng} / \mathrm{mL}$ and the detection limit of $\mathrm{HB}_{\mathrm{s}} \mathrm{Ag}$ was $3.3 \mathrm{fg} / \mathrm{mL}$ (signal-to-noise ratio of 3). Furthermore, the designed immunosensor with excellent selectivity, reproducibility and stability shows excellent performance in detection of human serum samples and provides a promising capacity for detecting a wide range of other tumor markers in clinical application [2].

\section{Dual-responsive competitive immunosensor for sensitive detection of tumor marker on g-CN/rGO conjugation.}

A new dual mode competitive immunosensing platform for sensitive determination of AFP combined photoelectrochemical and electrochemical methods was designed on graphite carbon nitride and reduced graphene oxide (g-CN/rGO) conjugate support. To construct such versatile support, polyamidoamine dendrimer (PAAD) decorated graphene oxide as substrate was reduced via poten-tiostatic technology, and the prepared rGO-PAAD nanocomposite was utilized as matrix to immobilize g-CN and capture antigen, and as electron transporter to mediate electron transfer for enhancement of photoelectrochemical and electrochemical signals. And then, horseradish peroxidase labeled antibody was competitively captured onto sensing interface with free antigen in incubated solution. Photoelectrochemical signal originated from g-CN, an excellent photoactive material with large photo-induced electric response, and was amplified by rGO-PAAD nanocomposite. The resultant concentration positively related linear calibration range was from $1 \mathrm{pg} / \mathrm{mL}$ to $40 \mathrm{ng} / \mathrm{mL}$ with ultralow detection limit of $1 \mathrm{pg} / \mathrm{mL}$. On the other hand, the enzyme-induced electrocatalytical signal amplification was produced by using hydroquinone as reactive substrate and horseradish peroxidase as reactive enzyme in existence 
of $\mathrm{H}_{2} \mathrm{O}_{2}$, which displayed a wide dynamic linear range from $0.1 \mathrm{ng} / \mathrm{mL}$ to $160 \mathrm{ng} / \mathrm{mL}$ with low detection limit of $0.1 \mathrm{ng} / \mathrm{mL}$. Additionally, the satisfying selectivity, good reproducibility and high consistency of dual-signal outputs of this designed dual-responsive immunosensor demonstrated the promising application in developing sensitive and accurate immunosensor for clinical test and disease diagnosis [11].

\section{A sandwich-type electrochemical immunosensor based on in situ silver deposition for determination of serum level in breast cancer patients.}

The sensitive quantification of human epidermal growth factor receptor 2 (HER2), as a key prognostic tumor marker, plays a critical role in screening, early diagnosis and management of breast cancer. This paper describes a sandwich-type immunoassay with silver signal enhancement strategy for highly sensitive detection of HER2. For this purpose, the target capturing step was designed by functionalization of 3-aminopropyltrimethoxysilane coated magnetite nanoparticles with antibody (antiHER2/APTMS$\mathrm{Fe}_{3} \mathrm{O}_{4}$ ), as a platform bioconjugate, and immobilized at a bare GCE. Then, in the presence of label-free immunosensor, the platform bioconjugate was covered by magnetic gold nanoparticles self-assembled with thiolated antibodies (antiHER2/Hyd@AuNP_APTMS- $\mathrm{Fe}_{3} \mathrm{O}_{4}$ ) containing chemically reduced silver ions, as a label bioconjugate. Under optimum conditions, a linear relationship between the differential pulse voltammetry stripping signal of silver and the logarithm of HER2 concentrations was obtained in the range of $5.0 \times 10^{-4}-50.0 \mathrm{ng} / \mathrm{mL}(\mathrm{R} 2=0.9906)$ with a detection limit of $2.0 \times 10^{-5} \mathrm{ng} / \mathrm{mL}$. The effectiveness of this protocol was evaluated experimentally through employing of designed immunosensor for detection of the serum level of tumor marker [4]. The good consistency of the results with those obtained by the enzyme-linked immunosorbent assay (ELISA) conventional method ( $\mathrm{p}$-value of $<0.05$ ) showed that this immunosensor can be applied for the testing of HER2 in clinical samples of breast cancer patients.

\section{Conclusions}

Immunosensors create a very promising tool that allows you to quickly, inexpensively and accurately measure different biophysiological information. They are widely used in medicine, especially in diagnostics.

Considering the development of immunosensors, scientific problems and future trends, immunosensors have become very interesting and open enormous opportunities for scientists, engineers and doctors.

\section{Література.}

1. Advancements and application of immunosensors in the analysis of food contaminants / M. S. Azam, M. R. T. Rahman, Z. Lou [et al.] // Nusantara Bioscience. - 2014. - Vol. 6, No. 2. - P. 186-195.

2. An ultrasensitive sandwich-type electrochemical immunosensor based on the signal amplification system of double-deck gold film and thionine unite with platinum nanowire inlaid globular SBA-15 microsphere / P. Wang, M. Li, F. Pei [et al.] // Biosens. Bioelectron. — 2017. — Vol. 91. — P. 424-430.

3. A sandwich-type electrochemical immunoassay for ultrasensitive detection of non-small cell lung cancer biomarker CYFRA21-1 / Y. Zeng, J. Bao, Y. Zhao [et al.] // Bioelectrochemistry. — 2018. — Vol. 120. P. 183-189.

4. A sandwich-type electrochemical immunosensor based on in situ silver deposition for determination of serum level of HER2 in breast cancer patients / M. Shamsipur, M. Emami, L. Farzin, R. Saber // Biosens. Bioelectron. - 2018. - Vol. 103. - P. - 54-61.

5. A sensitive sandwich-type immunosensor for the detection of galectin-3 based on N-GNRs-Fe-MOFs@AuNPs nanocomposites and a novel AuPt-methylene blue nanorod / Z. Tang, J. He, J. Chen [et al.] // Biosens. Bioelectron. - 2018. - Vol. 101. - P. 253-259.

6. Bojorge Ramirez N. The evolution and development of immunosensors for health and environmental monitoring: problems and perspectives / N. Bojorge Ramírez, A. M. Salgado, B. Valdman // Brazilian J. Chem. Eng. — 2009. — Vol. 26, No. 2. - P. 227-229.

7. Comparison of new ELISA kit (Recombisia Malaria AB Test with Microscopic-Detection of Malaria / M. Polder, H. Khanum, R. Elami [et al.] // Modern Biotechniques and Biotechnology. - 2015. - P. 237-243.

8. Competitive amperometric immunosensor for determination of p53 protein in urine with carbon nanotubes/gold nanoparticles screen-printed electrodes: a potential rapid and noninvasive screening tool for early diagnosis of urinary tract carcinoma / M. Giannetto, M. V. Bianchi, M. Mattarozzi, M. Careri // Anal. Chim. Acta. — 2017. — Vol. 991. — P. 133-141.

9. Cruz H. J. Immunosensors for diagnostic applications / H. J. Cruz, C. C. Rosa, A. G. Oliva // Parasitol. Res. 2002. - Vol. 88, Suppl. 1. - P. S4-7.

10. Development of evanescent wale all-fiber immunosensor for environmental water analysis / F. Long, M. He, H. C. Shi, A. Zhu // Biosensors Bioelectronics. 2008. - Vol. 23, No. 7. - P. 952-958.

11. Dual-responsive competitive immunosensor for sensitive detection of tumor marker on g-CN/rGO conjugation / H. Yan, L. Gong, L. Zang [et al.] // Sensors 
and Actuators B: Chemical. — 2016. — Vol. —230. — P. 810-817.

12. Effective immobilization of $\mathrm{Au}$ nanoparticles on TiO2 loaded graphene for a novel sandwich-type immunosensor / Y. Chen, Y. Li, D. Deng [et al.] // Biosens. Bioelectron. — 2018. — Vol. 102. — P. 301306.

13. Evaluation of two indigenous rapid and two ELISA assays for diagnosis of HIV infection India / H. S. Igbal, S. Solomon, K. G. Murugavel [et al.] // Indian J. Med. Microbiol. - 2012. - Vol. 30, No. 4. - P. 397-402.

14. Facile fabrication of an ultrasensitive sandwich-type electrochemical immunosensor for the quantitative detection of alpha fetoprotein using multifunctional mesoporous silica as platform and label for signal amplification / Y. Wang, X. Li, W. Cao [et al.] // Talanta. - 2014. — Vol. 129. - P. 411-416.

15. IgG avidity ELISA test for diagnosis of acute toxoplasmosis in humans / A. H. Rahbari, H. Keshavarz, S. Shojaee [et al.] // Korean J. Parasitol. — 2012. — Vol. 50, No. 2. - P. 99-102.

16. Immunologia / J. Gołąb, M. Jakóbisiak, W. Lasek, T. Stokłosa (Eds.). — Warszawa : Wydawnictwo Naukowe PWN, 2017. — 497 s.

17. Medyanseva E. Immunosensors in biology and medicine: analytical capabilities, problems and prospects / E. Medyanseva, E. Khaldeeva, G. Budnikov // J. Anal. Chem. - 2001. - Vol. 56. — P. 1015-1031.

18. Shankaran D. R. Recent advencements in surface plasmon resonance immunosensor for detection of small molecules of biomedical, food, environmental interest / D. R. Shankaran, K. V. Gobi, N. Miura // Sensors and Actuators B: Chemical. — 2007. — Vol. 121, No 1. — P. 158-177.

19. Tokarskyy O. Immunosensors for rapid detection of Escherichia coli 0157:H7 - perspective for use in the meat processing industry / O. Tokarskyy, D. L. Marshall // Food Microbilogy. — 2008. — Vol. 25, No. 12. - P. 1-12.

\section{References.}

1. Azam, M. S., Rahman, M. R. T., Lou, Z., Tang, Y., Raqib, S. M., \& Jothi, J. S. (2014). Advancements and application of immunosensors in the analysis of food contaminants. Nusantara Bioscience, 6(2), 186-195. doi: 10.13057/nusbiosci/n060212.

2. Wang, P., Li, M., Pei, F., Li, Y., Liu, Q., Dong, Y., Chu, Q., \& Zhu, H. (2017). An ultrasensitive sandwich-type electrochemical immunosensor based on the signal amplification system of double-deck gold film and thionine unite with platinum nanowire inlaid globular SBA-15 microsphere. Biosens. Bioelectron., 91, 424430. doi: org/10.1016/j.bios.2016.12.057.

3. Zeng, Y., Bao, J., Zhao, Y., Huo, D., Chen, M., Qi, Y., Yang, M., ... Hou, C. (2018). A sandwich-type electrochemical immunoassay for ultrasensitive detection of non-small cell lung cancer biomarker CYFRA21-1. Bioelectrochemistry, 120, 183-189, doi: org/10.1016/j.bioelechem. 2017.11.003.

4. Shamsipur M., Emami M., Farzin L., \& Saber R. (2018). A sandwich-type electrochemical immunosensor based on in situ silver deposition for determination of serum level of HER2 in breast cancer patients. Biosens. Bioelectron., 103, 54-61. doi: org/10.1016/j. bios.2017.12.022.

5. Tang, Z., He, J., Chen, J., Niu, Y., Zhao, Y., Zhang, Y., \& Yu, C. (2018). A sensitive sandwich-type immunosensor for the detection of galectin-3 based on N-GNRs-Fe-MOFs@AuNPs nanocomposites and a novel AuPt-methylene blue nanorod. Biosens. Bioelectron., 101, 253-259. doi: org/10.1016/j. bios.2017.10.026.

6. Bojorge Ramirez, N., Salgado, A. M., \& Valdman, B. (2009). The evolution and development of immunosensors for health and environmental monitoring: problems and perspectives. Brazilian J. Chem. Eng., 26, 227-229. doi: org/10.1590/S0104-66322009000200001.

7. Polder, M., Khanum, H., Elami, R., Mohan, A, Mohiuddin, M, \& Alam, M. (2015) Comparison of new ELISA kit (Recombisia Malaria AB Test with Microscopic-Detection of Malaria. Modern Biotechniques and Biotechnology, 237-243.

8. Giannetto, M., Bianchi, M. V., Mattarozzi, M., \& Careri, M. (2017). Competitive amperometric immunosensor for determination of p53 protein in urine with carbon nanotubes/gold nanoparticles screen-printed electrodes: A potential rapid and noninvasive screening tool for early diagnosis of urinary tract carcinoma. Anal. Chim. Acta, 991, 133-141, doi: org/10.1016/j. aca.2017.09.005.

9. Cruz, H. J., Rosa, C. C, \& Oliva, A. G. (2002). Immunosensors for diagnostic applications Parasitol. Res., 88(Suppl. 1), 4-7. doi: 10.1007/s00436-0010559-2.

10. Long, F., He, M., Shi, H. C., \& Zhu, A. (2008). Developement of evanescent wale all-fiber immunosensor 
for enviromental water analysis. Biosens. Bioelectron., 23(7), 952-958. doi: org/10.1016/j.bios.2007.09.013.

11. Yan, H., Gong, L., Zang, L., Dai, H., Xu, G., Zhang, S., \& Lin, Y. (2016). Dual-responsive competitive immunosensor for sensitive detection of tumor marker on g-CN/rGO conjugation. Sensors and Actuators B: Chemical, 230, 810-817. doi: org/10.1016/j. snb.2016.02.144.

12. Chen, Y., Li, Y., Deng, D., He, H., Yan, X., Wang, Z., Fan, C., \& Luo, L. (2018). Effective immobilization of Au nanoparticles on $\mathrm{TiO} 2$ loaded graphene for a novel sandwich-type immunosensor. Biosens. Bioelectron., 102, 301-306. doi: org/10.1016/j.bios.2017.11.009.

13. Igbal, S. H., Solomon, S, Murugavel, K. G., Solomon, S. S., \& Blakrishnan, P. (2012). Evaluation of two indigenous rapid and two ELISA assays for diagnosis of HIV infection India. Indian J. Med. Microbiol., 30(4), 397-402. doi: org/10.4103/02550857.103758.

14. Wang, Y., Li, X., Cao, W., Li, Y., Li, H., Du, B., \& Wei, Q. (2014). Facile fabrication of an ultrasensitive sandwich-type electrochemical immunosensor for the quantitative detection of alpha fetoprotein using multifunctional mesoporous silica as platform and label for signal amplification. Talanta, 129, 411-416, doi: org/10.1016/j.talanta.2014.06.017.

15. Rahbari, A. H., Keshavarz, H., Shojaee, S., Mohebali, M., \& Rezaeian, M. (2012) IgG avidity ELISA test for diagnosis of acute toxoplasmosis in humans. Korean J. Parasitol., 50(2), 99-102. doi: org/10.3347/ kjp.2012.50.2.99.

16. Gołąb, J, Jakóbisiak, M, Lasek, W, \& Stokłosa, T. (Eds.). (2013). Immunologia. Warszawa: Wydawnictwo Naukowe PWN.

17. Medyanseva, E, Khaldeeva, E, \& Budnikov, G (2001). Immunosensors in biology and medicine: analytical capabilities, problems and prospects. J. Anal. Chem., 56, 1015-1031. doi: org/10.1023/A:1012345025093.

18. Shankaran, D. R., Gobi, K. V., \& Miura, N. (2007) Recent advencements in surface plasmon resonance immunosensor for detection of small molecules of biomedical, food, enviromnetal interst. Sensors and Actuators B: Chemical, 121(1), 158-177. doi: org/10.1016/j.snb.2006.09.014.

19. Tokarskyy, O, \& Marshall, D. (2008). Immunosensors for rapid detection of Escherichia coli 0157:H7 perspective for use in the meat processing industry. Food Microbilogy, 25(12), 1-12. doi: org/10.1016/ jfm.2007.07.005. 